\title{
PENERAPAN LESSON STUDY PADA MATA KULIAH PEMBELAJARAN IPS PRODI PENDIDIKAN GURU MADRASAH IBTIDAIYAH INSTITUT AGAMA ISLAM YASNI BUNGO 2019/2020
}

\author{
Fitria Carli Wiseza \\ Institut Agama Islam Yasni Bungo \\ Email: Fitriawiseza@gmail.com
}

\begin{abstract}
The purposes of the lesson study are (1) describing the application of lesson study to improve the soft skills of students in the social studies subject, (2) increasing the independence of the students' way of learning outside and inside the classroom, (3) improvement of the learning process that accommodates the various interests of students, (4) Improvement on the conducive climate of student learning by sharpening the cognitive and foster the compassion, (5) revealing the best practices conducted by the lecturers and students during the learning process. Lesson study was conducted in Indonesian Language and Literature Department in the studies social subject language learning five B and C from 5 and of Nov 212019 to 24 th of Sept 2019. One cycle of lesson study consists of planning (plan), action (do) and reflection (see), and the learning was divided into four cycles. Student who is taking a course of studies social is engaged in lesson study as a subject of learning. The final target of this study is that the students can improve their skills in make video studies Social. The results achieved were: (1) lesson study was conducted by using cooperative learning model to improve the soft skills of the students, (2) The independence of student learning can be seen in the discussion session and alongside the process of mutual sharpening the cognitive and foster the compassion and make video studies social (3) students were more excited and have better concentration because of the students worksheets on all learning process and a particular approach from the lecturer of the subject, (4) There were process of mutual sharpening of the cognitive and foster the compassion on the learning process, (5) There were processes of group planning on the learning by the teaching team, giving correction among colleagues, and learning evaluation process involving faculty members and students.
\end{abstract}

Keywords: Lesson Study, Soft Skills, Social Studies

\begin{abstract}
Abstrak
Tujuan lesson study ini (1) Mendeskripsikan penerapan lesson study untuk meningkatkan soft skill mahasiswa dalam mata kuliah Pembelajaran IPS, (2) Peningkatan kemandirian cara belajar mahasiswa baik di luar kelas maupun di dalam kelas,(3)Peningkatan proses pembelajaran yang mengakomodasi kepentingan mahasiswa yang bervariasi,(4)Peningkatan iklim belajar yang
\end{abstract}

Nur El-Islam, Volume 7, Nomor 1, April 2020 
Penerapan Lesson Study ...

kondusif bagi mahasiswa dengan cara asah, asih dan asuh,(5)mengungkapkan praktik baik (best practices) yang dilakukan dosen dan mahasiswa selama proses pembelajaran berlangsung. Lesson study dilaksanakan di Prodi Pendidikan pendidikan Guru Madrasah Ibtidayah (PGMI) pada matakuliah pembelajaran IPS Semester V kelas B 5-21 November 2019. Satu siklus lesson study terdiri atas perencanaan (plan), tindakan (do), dan refleksi (see). Pembelajaran ini dibagi dalam empat siklus. Mahasiswa yang menempuh matakuliah pembelajaran IPS terlibat dalam kegiatan lesson study sebagai subjek pembelajaran. Target akhir dalam pembelajaran ini adalah mahasiswa dapat meningkatkan keterampilannya dalam membuat video pembelajaran secara mandiri dimana sebagai guru dan siswa kelompok permasing-masing mahasiswa. Hasil yang dicapai adalah (1) Lesson study dilakukan dengan model pembelajaran cooperatif learning untuk meningkatkan soft skill mahasiswa, (2) Kemandirian belajar mahasiswa dapat terlihat dalam sesi diskusi dan ada proses saling asah, asih, dan asuh serta hasil pembuata video pembelajaran secara mandiri (3) Mahasiswa lebih bersemangat dan berkonsentrasi dengan adanya pengisian lembar kerja mahasiswa pada setiap proses pembelajaran dan adanya pendekatan khusus dari dosen pengampu mata kuliah, (4) Ada proses saling asah, asih, dan asuh dalam proses pembelajaran, (5) Ada proses menyusun perencanaan pembelajaran secara bersama-sama oleh tim pengajar, saling memberi koreksi antar kolega, dan proses evaluasi pembelajaran yang melibatkan dosen dan mahasiswa.

Kata kunci: Pendekatan pembelajaran, Ketrampilan, Pembelajaran IPS

\section{A. Pendahuluan}

Proses perkuliahan merupakan proses pengembangan potensipotensi mahasiswa sebagai peserta didik secara menyeluruh dan terpadu. Dosen dituntut untuk menguasai berbagai kemampuan profesional dalam bidangnya. Selanjutnya dosen dituntut menyampaikan materi kuliah dengan strategi pembelajaran yang tepat sesuai tujuan. Oleh karena itu, pembelajaran yang dilakukan harus dapat membekali peserta didik dengan kompetensi matakuliah yang bersifat lintas disiplin. Pelaksanaan perkuliahan setiap saat selalu mengalami perubahan sesuai dengan tujuan dan kebutuhan perkuliahan itu sendiri. Dalam praktiknya, setiap mahasiswa memiliki kemampuan yang bervariasi selama mengikuti proses perkuliahan.

Sesuai dengan orientasi program Fakultas Tarbiyah yaitu mencetak pendidik profesional yang Islami dan berdaya saing unggul, maka semua mahasiwa harus dibekali dengan seperangkat kompetesi yang mampu mewujudkan visi ke depan sesuai dengan tuntutan zaman. Hal yang tidak kalah penting dalam mempersiapkan mahasiswa untuk bersaing dan mempunyai kompetensi yang diprasyaratkan tentunya harus didukung dengan proses perkuliahan yang memadai. 
Proses perkuliahan yang memadai salah satunya bagaimana mahasiswa dapat mengikuti perkuliahan secara baik dan memperoleh hasil yang optimal.

Salah satu matakuliah yang mampu membekali mahasiswa dalam menangkap persoalan, berpikir kritis, kreatif, dan inovatif serta menunjang pemenuhan kompetensi sebagai seorang guru yaitu matakuliah Pembelajaran IPS. Dalam mata kuliah ini, mahasiswa diharapkan dapat mempraktekkan Proses Belajar Mengajar secara mandiri dalam pembuatan video pembelajaran secara mandiri permasing kelompok mahasiswa sebagai subjek (Guru) dan objek (Siswa) secara logis dan sistematis sesuai dengan problem pembelajaran di kelas. Dengan demikian mahasiswa dituntut untuk terus mengembangkan diri dalam mengasah kemampuannya sehingga dapat memenuhi tugas akhir berupa Video praktek Pembelajaran. Tuntutan berupa kemampuan dan kerja keras yang begitu tinggi belum disertai dengan proses pembelajaran yang baik. Berdasarkan pengamatan selama ini, perkuliahan Pembelajaran belum berlangsung secara optimal.

Hal ini disebabkan model pembelajaran belum memberikan keleluasaan mahasiswa untuk melakukan aktivitas dalam mengekplorasi ide/gagasan secara optimal, mahasiswa cenderung kurang aktif dan berpikir minimalis. Meskipun orientasi perkuliahan sudah menggunakan paduan antara ceramah dan diskusi namun ternyata hasilnya masih belum maksimal. Di samping itu, interaksi antara mahasiswa yang satu dengan yang lainnya belum terjalin, begitu pula interaksi mahasiswa dengan lingkungan masih sangat kurang. Kurangnya interaksi tersebut menyebabkan mahasiswa merasa kesulitan mengeksplorasi ide yang akhirnya dalam bentuk pembuatan video praktek pembelajaran.

Sehubungan dengan permasalahan yang ditemukan dalam proses pembelajaran serta adanya tuntutan peningkatan kualitas proses pembelajaran, maka perlu kiranya mengimplementasikan pembelajaran lesson study. Lesson study memberikan kesempatan kepada dosen untuk melakukan pengkajian pembelajaran secara kolaboratif dan berkelanjutan guna membangun komunitas belajar 
yang lebih baik sesuai dengan situasi, kondisi dan permasalahan yang dihadapi dosen.

Lesson study sebagai suatu kegiatan yang diawali dengan pengembangan perencanaan secara bersama-sama, proses pembelajaran terbuka dengan melibatkan sejumlah observer, dan refleksi atau diskusi pasca pembelajaran, merupakan suatu kegiatan yang sangat potensial untuk menciptakan proses interaksi antarberbagai pihak. Dengan model seperti ini tidak menutup kemungkinan akan memunculkan berbagai inovasi pembelajaran. Selain itu, dengan model pengembangan interaksi dalam lesson study ternyata dapat secara konstruktif menunjang proses berkembangnya pengetahuan dalam diri seseorang. ${ }^{1}$

Penerapan lesson study dalam proses pembelajaran merupakan salah satu langkah yang baik untuk mencapai tujuan pendidikan sebagaimana tercantum dalam Undang-Undang nomor 20 tahun 2003 tentang Sistem Pendidikan Nasional. Di dalam Undang-Undang tersebut disebutkan bahwa pendidikan nasional berfungsi mengembangkan kemampuan dan membentuk watak serta peradaban bangsa yang bermartabat dalam rangka mencerdaskan kehidupan bangsa. Pendidikan bertujuan untuk mengembangkan potensi peserta didik agar menjadi manusia yang beriman dan bertakwa kepada Tuhan Yang Maha Esa, berakhlak mulia, sehat, berilmu, cakap, kreatif, mandiri, dan menjadi warga negara yang demokratis serta bertanggung jawab.

Dalam rangka mencapai tujuan pendidikan ini, dosen dituntut bersikap profesional. Sikap profesional dosen bukan sekadar mempunyai pengetahuan teknologi dan manajemen tetapi juga mempunyai sikap yang dapat mengarahkan dan membimbing mahasiswa agar dapat belajar dalam arti yang sebenarnya. Tugas utama seorang dosen adalah menyelenggarakan kegiatan pembelajaran. Agar kegiatan itu terselenggara dengan efektif, seorang dosen harus mengetahui hakikat kegiatan belajar, mengajar, dan

\footnotetext{
${ }^{1}$ Kesuma, Dharma, dkk, Pendidikan Karakter, Kajian Teori dan Praktik di Sekolah (Bandung: PT. Remaja Rosdakarya, 2011), h.25.
} 
strategi pembelajaran. Dengan demikian, seorang dosen harus mengenali potensi dan kemampuan mahasiswa, menguasai strategi pembelajaran yang dipilih dan disesuaikan dengan kondisi mahasiswa, menguasai materi atau bahan ajar dengan baik, serta selalu melakukan evaluasi untuk meningkatkan kualitas pembelajaran. ${ }^{2}$

Di samping profesionalisme dosen, pembelajaran juga terkait erat dengan subjek belajar, yaitu mahasiswa. Ada beberapa faktor yang mempengaruhi belajar mahasiswa, yaitu faktor yang ada pada diri mahasiswa dan faktor yang berasal dari luar mahasiswa. ${ }^{3}$ Faktor minat, motif, dan perhatian dari dalam diri mahasiswa perlu dimunculkan, karena faktor inilah yang sangat menentukan keberhasilan mahasiswa dalam belajar. Dalam hal ini, peran dosen akan sangat membantu untuk memunculkan faktor ini. Dengan bantuan, bimbingan, dan arahan dari dosen, mahasiswa diharapkan akan menjadi pribadi yang matang, kreatif, inovatif, dan mandiri. Dengan kata lain, mahasiswa akan melangkah ke arah yang lebih baik, karena pada hakikatnya belajar merupakan proses menuju ke arah yang lebih baik dengan cara sistematis. Bruner mengemukakan bahwa proses belajar yang sistematis terdiri dari tiga tahapan, yaitu tahap informasi, transformasi, dan evaluasi. ${ }^{4}$

Belajar berarti proses perubahan tingkah laku pada mahasiswa akibat adanya interaksi antara individu dan lingkungannya melalui pengalaman dan latihan. Perubahan ini terjadi secara menyeluruh, menyangkut aspek kognitif, afektif, dan psikomotor. Pemerintah menjadikan pembangunan karakter sebagai salah satu program prioritas pembangunan nasional. Semangat itu secara implisit ditegaskan dalam Rencana Pembangunan Jangka Panjang Nasional (RPJPN) tahun 2010-2020, di mana pendidikan karakter ditempatkan

${ }^{2}$ Sugiarti, dkk, “Peningkatan Kemandirian dan Daya Kritis Mahasiswa Semester V Prodi Bahasa, Sastra Indonesia dan Daerah FKIP UMM pada Mata kuliah Penelitian Bahasa dan Sastra Indonesia”, makalah Seminar Lesson Study FKIP UMM, 2012.

${ }^{3}$ Slameto, Belajar dan Faktor-Faktor yang Mempengaruhinya (Jakarta: Rineka Cipta, 2009),h. 56

${ }^{4}$ Sugiyono. Metode Penelitian Kuantitatif Kualitatif dan $R \& D$ (Bandung: Alfabeta, 2010), h.67. 
sebagai landasan untuk mewujudkan visi pembangunan nasional, yaitu "mewujudkan masyarakat berakhlak mulia, bermoral, beretika, berbudaya. Dengan demikian dapat dikatakan bahwa penerapan lesson study sejalan dengan program pemerintah tentang pembentukan sikap dan tingkah laku siswa melalui pendidikan karakter beradab berdasarkan falsafah Pancasila”

Hasil yang diharapkan dari pelaksanaan LS ini adalah (1) Peningkatan kemandirian cara belajar mahasiswa baik di luar kelas maupun di dalam kelas, (2) Peningkatan proses pembelajaran yang mengakomodasi kepentingan mahasiswa yang bervariasi,(3) Peningkatan iklim belajar yang kondusif bagi mahasiswa dengan cara asah, asih dan asuh, (4) Peningkatan kualitas pembelajaran secara berkesinambungan,(5) Mengungkapkan praktik baik (best practices) yang dilakukan dosen dan mahasiswa selama proses pembelajaran berlangsung.

Lesson Study dilaksanakan di Program Studi Pendidikan Bahasa dan Sastra Indonesia pada mata kuliah Pembelajaran IPS Prodi PGMI Semester V kelas B dan C mulai tanggal 5-21 November 2019. Agenda dan Uraian Kegiatan Agenda dan kegiatan lesson study.

Tabel 1. Agenda dan Kegiatan Lesson Study

\begin{tabular}{|c|c|c|c|c|}
\hline Tanggal & Kegiatan & Pukul & Tempat & Uraian \\
\hline $\begin{array}{l}05 \\
\text { November } \\
2019\end{array}$ & Plan I & $\begin{array}{l}10.00 \\
- \\
11.30\end{array}$ & $\begin{array}{l}\text { Ruang } \\
\text { Dosen }\end{array}$ & $\begin{array}{lr}\text { Plan I berisi rencana } \\
\text { pembelajaran yang akan } \\
\text { dilaksanakan pada Do I. } \\
\text { Materi yang } & \text { akan } \\
\text { disampaikan pada } & \text { Do I } \\
\text { adalah penentuan } & \text { topik } \\
\text { materi } & \text { dan } \\
\text { mengembangkan. } & \\
& \\
\text { PendekatanpadaMatakuliah } \\
\text { Pembelajaran IPS } \\
\text { digunakan dalam proses } \\
\text { pembelajaran } & \text { adalah }\end{array}$ \\
\hline
\end{tabular}




\begin{tabular}{|c|c|c|c|c|}
\hline & & & & $\begin{array}{l}\text { pendekatan kooperatif dan } \\
\text { inkuiri. Adapun metode } \\
\text { pembelajaran } \\
\text { digunakan adalah diskusi } \\
\text { dengan teknik ceramah, } \\
\text { Tanya jawab } \\
\text { penugasan. } \\
\text { Indikator } \\
\text { pembelajaran IPS siklus I } \\
\text { ini: } \\
\text { IPS berbasis Masalah. }\end{array}$ \\
\hline $\begin{array}{l}06 \\
\text { September } \\
2019\end{array}$ & Do I & $\begin{array}{l}09.30 \\
- \\
11.00\end{array}$ & $\begin{array}{l}\text { Ruang } \\
\text { A.I.I }\end{array}$ & $\begin{array}{l}\text { Do I dilaksanakan sesuai } \\
\text { dengan Plan I. } \\
\text { Mahasiswa berdiskusi } \\
\text { sesuai materi kelompok. }\end{array}$ \\
\hline $\begin{array}{l}06 \\
\text { September } \\
2019\end{array}$ & See I & - & $\begin{array}{l}\text { Ruang } \\
\text { A.I.I }\end{array}$ & $\begin{array}{l}\text { See I merupakan kegiatan } \\
\text { evaluasi dan refleksi } \\
\text { terhadap do I yang baru saja } \\
\text { dilakukan. }\end{array}$ \\
\hline $\begin{array}{l}13 \\
\text { November } \\
2019\end{array}$ & Plan II & $\begin{array}{l}09.30 \\
- \\
11.00\end{array}$ & $\begin{array}{l}\text { Ruang } \\
\text { Dosen }\end{array}$ & 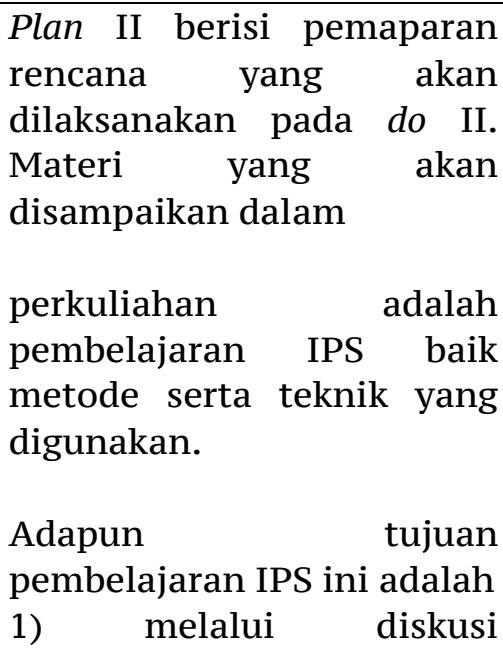 \\
\hline
\end{tabular}




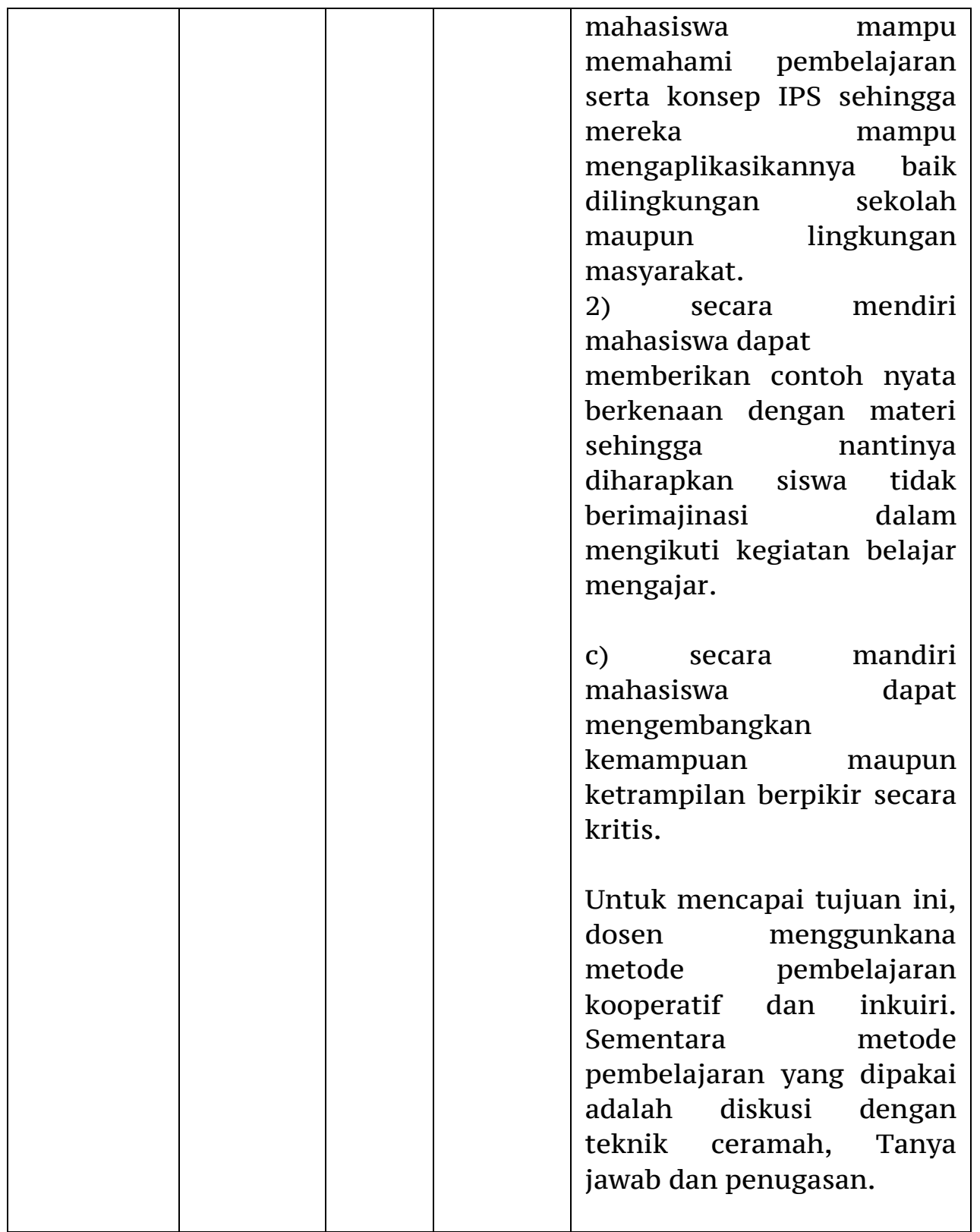




\begin{tabular}{|c|c|c|c|c|}
\hline $\begin{array}{l}14 \\
\text { November } \\
2019\end{array}$ & Doo II & $\begin{array}{l}09.30 \\
- \\
11.00\end{array}$ & $\begin{array}{l}\text { Ruang } \\
\text { Pustaka }\end{array}$ & $\begin{array}{l}\text { Mahasiswa mencari } \\
\text { referensi dan membuat } \\
\text { kajian pustaka } \\
\text { Mahasiswa mengisi lembar } \\
\text { kerja mahasiswa yang berisi } \\
\text { poin-poin kajian pustaka. }\end{array}$ \\
\hline $\begin{array}{l}14 \\
\text { November } \\
2019\end{array}$ & See II & $\begin{array}{l}09.30 \\
- \\
11.00\end{array}$ & $\begin{array}{l}\text { Ruang } \\
\text { Pustaka }\end{array}$ & $\begin{array}{l}\text { See II dilaksanakan seusai } \\
\text { do II di ruang pustaka } \\
\text { 1. Kegiatan see II } \\
\text { bertujuan untuk } \\
\text { mengevaluasi dan } \\
\text { merefleksi kegiatan } \\
\text { do II. }\end{array}$ \\
\hline $\begin{array}{l}15 \\
\text { November } \\
2019\end{array}$ & Plan III & $\begin{array}{l}09.00 \\
- \\
10.00\end{array}$ & $\begin{array}{l}\text { Ruang } \\
\text { Dosen }\end{array}$ & $\begin{array}{l}\text { Dosen merencanakan } \\
\text { materi pembelajaran yang } \\
\text { akan disampaikan pada do } \\
\text { III adalah konsep } \\
\text { kurikulum serta kurikulum } \\
13 \\
\text { Tujuan pembelajaran IPS } \\
\text { pada siklus III ini adalah a) } \\
\text { melalui diskusi mahasiswa } \\
\text { mampu memahami konsep } \\
\text { kurikulum serta memahami } \\
\text { pemakaian kurikulum } 13 \\
\text { dengan baik. } \\
\text { b) secara mand } \\
\text { mandiri mahasiswa dapat } \\
\text { mempraktekkan metode, } \\
\text { teknik serta konsep dalam } \\
\text { mengajar. } \\
\text { c) secara mandiri }\end{array}$ \\
\hline
\end{tabular}




\begin{tabular}{|c|c|c|c|c|}
\hline & & & & $\begin{array}{l}\text { mahasiswa dapat } \\
\text { mengembangkan } \\
\text { ketrampilan dan } \\
\text { kemampuan secara kritis } \\
\text { dan } \\
\text { inovatif Untuk mencapai } \\
\text { tujuan ini, dosen model } \\
\text { menggunakan metode } \\
\text { diskusi dan memakai teknik } \\
\text { ceramah, Tanya jawab dan } \\
\text { penugasan. } \\
\text { Adapun pendekatan yang } \\
\text { digunakan adalah } \\
\text { kooperatif dan inkuiri. }\end{array}$ \\
\hline $\begin{array}{l}19 \\
\text { November } \\
2019\end{array}$ & Do III & $\begin{array}{l}08.00 \\
- \\
09.30\end{array}$ & $\begin{array}{l}\text { Ruang } \\
\text { A.I.I }\end{array}$ & $\begin{array}{l}\text { Do III dilaksanakan sesuai } \\
\text { dengan plan III, yaitu } \\
\text { mahasiswa menganalisis } \\
\text { dan menginterpretasikan } \\
\text { konsep serta kurikulum } 13 \\
\text { melalui diskusi dan mengisi } \\
\text { lembar kerja mahasiswa. }\end{array}$ \\
\hline $\begin{array}{l}19 \\
\text { November } \\
2019\end{array}$ & See III & $\begin{array}{l}09.30 \\
- \\
10.00\end{array}$ & $\begin{array}{l}\text { Ruang } \\
\text { A.I.I }\end{array}$ & $\begin{array}{l}\text { See III dilaksanakan setelah } \\
\text { do III selesai dilaksanakan. } \\
\text { Hal ini bertujuan agar hasil } \\
\text { pengamatan observer dapat } \\
\text { langsung tersampaikan dan } \\
\text { pengalaman pada do III } \\
\text { dapat segera ditanggapi } \\
\text { dengan baik. }\end{array}$ \\
\hline $\begin{array}{l}20 \\
\text { November } \\
2019\end{array}$ & Plan IV & $\begin{array}{l}10.00 \\
- \\
11.00\end{array}$ & $\begin{array}{l}\text { Ruang } \\
\text { Dosen }\end{array}$ & $\begin{array}{l}\text { Plan IV berisi rencana } \\
\text { pembelajaran yang akan } \\
\text { disampaikan pada do IV. } \\
\text { Materi pembelajaran yang } \\
\text { akan disampaikan adalah }\end{array}$ \\
\hline
\end{tabular}




\begin{tabular}{|c|c|c|c|c|}
\hline & & & & $\begin{array}{l}\text { memahami pendidikan } \\
\text { karakter dalam } \\
\text { pembelajaran IPS. } \\
\text { Adapun tujuan } \\
\text { pembelajaran pada siklus } \\
\text { IV ini adalah } \\
\text { a) secara mandiri } \\
\text { mahasiswa mampu } \\
\text { menerapkan } \\
\text { pendidikan karakter } \\
\text { kepada peserta didik } \\
\text { nantinya. } \\
\text { b) Secara mahasiswa } \\
\text { mandiri map } \\
\text { dapat menjaga sikap } \\
\text { serta menunjukkan } \\
\text { perbuatan yang baik } \\
\text { di lingkungan } \\
\text { masyarakat. } \\
\text { dipakai adalah pendekatan } \\
\text { kooperatif dan inkuiri. } \\
\text { Metode pembelajaran yang } \\
\text { dipergunakan adalah } \\
\text { diskusi dengan teknik } \\
\text { ceramah, Tanya jawab dan } \\
\text { penugasan. }\end{array}$ \\
\hline $\begin{array}{l}21 \\
\text { November } \\
2019\end{array}$ & Do IV & $\begin{array}{l}08.30 \\
- \\
09.30\end{array}$ & $\begin{array}{l}\text { Aula } \\
\text { Kampus }\end{array}$ & $\begin{array}{lr}\text { Do IV } & \text { dilaksanakan } \\
\text { berdasarkan } & \text { plan IV, yaitu } \\
\text { mahasiswa } & \text { menyusun } \\
\text { kelompok } & \text { serta } \\
\text { topic yang }\end{array}$ \\
\hline
\end{tabular}




\begin{tabular}{|l|l|l|l|l|}
\hline & & & $\begin{array}{l}\text { akan dijadikan dalam } \\
\text { prakter mengajar dan } \\
\text { menyusun siapa yang } \\
\text { menjadi guru (subjek) dan } \\
\text { siswa (objek). }\end{array}$ \\
\hline $\begin{array}{l}\text { November } \\
2019\end{array}$ & See IV & 10.00 & $\begin{array}{l}\text { Aula } \\
\text { Kampus }\end{array}$ & $\begin{array}{l}\text { See IV dilaksanakan setelah } \\
\text { do IV untuk merefleksi dan } \\
\text { mengevaluasi proses } \\
\text { pembelajaran pada do IV. } \\
\text { Refleksi dan evaluasi } \\
\text { dilakukan tim lesson study } \\
\text { berdasarkan pengamatan } \\
\text { observer. }\end{array}$ \\
\hline
\end{tabular}

\section{B. Pembahasan}

Lesson Study (LS) adalah model pembinaan profesi dosen melalui pengkajian pembelajaran secara kolaboratif dan berkelanjutan berdasarkan prinsip-prinsip kolegalitas dan belajar saling menguntungkan untuk membentuk sebuah komunitas belajar. ${ }^{5} \mathrm{Di}$ dalam $L S$ tidak hanya berupa penerapan metode dan strategi pembelajaran, melainkan pemecahan persoalan pembel-ajaran dengan kolega pengamat dan memunculkan semangat dan kemandirian belajar mahasiswa. ${ }^{6}$ Pengalaman pembelajaran akan menghasilkan hasil proses belajar yang mandiri dan berkelanjutan. Kemampuan yang ada pada mahasiswa dalam kegiatan belajarnya dilakukan dengan berpikir, merasa, dan melakukan sesuatu serta belajar merencanakan belajar, memilih alternatif model belajar, mengatasi permasalahan dan tanggung jawab merupakan sasaran belajar mandiri dan

${ }^{5}$ Kemendiknas, Pedoman Penulisan Makalah Lesson Study untuk Seminar Exchange of Experience (Jakarta: Direktorat Pembelajaran dan Kemahasiswaan Direktorat Jenderal Pendidikan Tinggi Kementerian Pendidikan Nasional, 2012)

${ }^{6}$ Uno, Hamzah B dan Nurdin Mohamad, Belajar dengan Pendekatan PAILKEM: Pembelajaran Aktif, Inovatif, Lingkungan, Kreatif, Efektif, Menarik (Jakarta: PT. Bumi Aksara,2011), h. 27. 
berkelanjutan. Hal ini sangat terkait dengan perolehan hasil belajar yang bermakna.

Lesson study mendatangkan banyak manfaat, yaitu meningkatkan pengetahuan dosen tentang materi ajar dan pembelajarannya; meningkatkan pengetahuan dosen tentang cara mengobservasi aktivitas belajar mahasiswa; menguatkan hubungan kolegalitas antardosen; menguatkan hubungan antara pelaksanaan pembelajaran sehari-hari dengan tujuan pembelajaran jangka panjang; meningkatkan motivasi dosen untuk senantiasa berkembang dan meningkatkan kualitas rencana pembelajaran dan strategi pembelajaran. ${ }^{7}$

Lesson study di Prodi Pendidikan Guru Madrasah Ibtidayah dilaksanakan pada empat pertemuan mata kuliah Pembelajaran IPS, yaitu mulai tanggal 5-21 November 2019. Dalam satu minggu mahasiswa masuk kelas sebanyak 1 kali. Sebelum melaksanakan do, membuat persiapan atau menyusun skenario pembelajaran (plan). See dilakukan tepat setelah pelaksanaan do. lesson study secara bergiliran mendapatkan kesempatan untuk menjadi dosen model. Lesson study kali ini dilaksanakan dalam 3 siklus. Masing-masing siklus terdiri atas tiga tahapan. Pertama, plan (merencanakan), yaitu mendiskusikan materi ajar dan skenario pembelajaran yang dituangkan dalam RPP. Pada kegiatan ini dosen mendiskusikan konsep esensial serta kompetensi atau keterampilan yang perlu dipelajari oleh mahasiswa, membandingkan proses pembelajaran yang biasa dilakukan, serta mempertimbangkan pengetahuan yang sudah dimiliki mahasiswa, apa yang perlu dipelajari selanjutnya dan bagaimana perkiraan respon mahasiswa terhadap pembelajaran yang direncanakan. Perencanaan disusun oleh dosen model yang kemudian dicermati, didiskusikan dan disempurnakan dengan lesson study.

Langkah kedua dalam lesson study adalah pelaksanaan (do) pembelajaran untuk menerapkan rancangan pembelajaran yang telah dirumuskan dalam perencanaan. Sebelum pelaksanaan, dosen model melakukan briefieng dulu kepada para pengamat (observer) untuk

\footnotetext{
${ }^{7}$ Ibid
} 
mengingatkan bahwa selama pembelajaran berlangsung pengamat tidak mengganggu kegiatan pembelajaran tetapi mengamati aktivitas mahasiswa selama pembelajaran. Fokus pengamatan ditujukan pada interaksi mahasiswa, mahasiswa dengan bahan ajar, mahasiswa dengan dosen, dan mahasiswa dengan lingkungan. Lembar observasi pembelajaran dibagikan kepada para pengamat sebelum pembelajaran dimulai. Para pengamat dipersilakan mengambil tempat di ruang kelas yang memungkinkan dapat mengamati aktivitas mahasiswa. Pengamat dapat melakukan perekaman kegiatan pembelajaran melalui kamera atau video untuk keperluan dokumentasi dan bahan studi lebih lanjut.

Do I dilaksanakan sesuai dengan plan I. Dalam proses pembelajaran, mahasiswa berdiskusi untuk menyusun materi pembelajaran. Ada proses saling memberi dan menerima dalam rangka menyempurnakan materi. Namun demikian, ada beberapa mahasiswa kurang aktif dalam diskusi. Melihat kondisi seperti ini, dosen model memberi pengarahan dan merangsang agar mahasiswa lebih aktif. Do II berjalan lebih baik dari do I, namun ada beberapa mahasiswa yang masih perlu didorong/diberi kesempatan untuk mempresentasikan hasil diskusi kelompoknya agar kegiatan presentasi tidak terfokus pada mahasiswa pintar. Pada do II ini, mahasiswa lebih berkonsentrasi dalam belajar. Upaya yang dilakukan dosen untuk mengarahkan mahasiswa sudah baik. Namun demikian, dosen perlu memberikan kesempatan mahasiswa untuk mengeksplorasi materi.

Pada do III, ada beberapa masukan untuk perbaikan pembelajaran berikutnya, yaitu dosen model perlu memunculkan desain penelitian. Penjelasan yang diberikan oleh dosen model sebaiknya dikaitkan dengan penugasan sebelumnya. Indikator keberhasilan dalam proses pembelajaran mestinya mengarah pada persoalan yang akan diselesaikan. Ketika proses pembelajaran berlangsung, mahasiswa tampak kebingungan dengan lembar kerja mahasiswa yang diberikan oleh dosen model. Untuk mengatasi hal ini, dosen model segera memberikan penjelasan tentang bagaimana cara mengisi lembar kerja mahasiswa tersebut sekaligus menjelaskan istilah-istilah dalam metode penelitian PTK. Peran aktif siswa akan 
berdampak pada pembentukan generasi yang kreatif. Pada do III tampak peran aktif mahasiswa mempengaruhi motivasi mahasiswa untuk berbuat lebih. Semua ini disebabkan respon dosen model terhadap tugas/pekerjaan mahasiswa bagus dan mahasiswa merasakan manfaat pembelajaran dengan metode diskusi pada materi pembelajaran IPS. Sementara itu, pada do IV media yang dipakai oleh dosen model dinilai kurang jelas. Kekurangan ini dapat ditutupi dengan sikap dan bahasa dosen model yang komunikatif sehingga mahasiswa dapat memperoleh penjelasan yang komprehensif. Selain itu dosen model juga memberikan peluang kepada mahasiswa untuk mandiri. ${ }^{8}$

Langkah ketiga dalam lesson study adalah merefleksi (see). Setelah selesai pembelajaran langsung dilakukan diskusi antara dosen model, pengamat, dan melibatkan perwakilan peserta didik untuk membahas pembelajaran yang baru saja berlangsung. Dosen model mengawali diskusi dengan menyampaikan kesan-kesan dalam melaksanakan pembelajaran, selanjutnya pengamat(observer)diminta menyampaikan komentar dari pembelajaran terutama berkenaan dengan aktivitas mahasiswa. Kritik dan saran untuk dosen model juga disampaikan dengan bijak demi perbaikan pembelajaran. Secara rinci, kegiatan see meliputi:

1. Tim melakukan refleksi pembelajaran yang telah dilakukan dengan diskusi, dimulai dari guru model menyampaikan kesan dan pesan tentang praktik pembelajaran yang telah dilakukan.

2. Observer memberikan komentar tentang hal-hal yang baik selama kegiatan pembelajaran.

3. Observer memberikan komentar tentang hal-hal yang kurang baik disertai bukti-bukti dan langkah-langkah solusinya.

4. Tim menemukan praktik baik yang sudah dilakukan oleh guru model sebagai best practices.

5. Kegiatan dilanjutkan pada siklus berikutnya berdasarkan hasil refleksi.

${ }^{8}$ Hendayana, Sumar, dkk, Lesson Study, Suatu Strategi Untuk Peningkatan Keprofesionalan Pendidik (Bandung: FPMIPA UPI dan JICA,2011), h.67. 
Kegiatan see selalu dilakukan setelah kegiatan do dilakukan. Hasil refleksi pada see I adalah dosen model perlu lebih mendorong mahasiswa untuk aktif dalam proses pembelajaran, sehingga ada proses belajar bersama. Selain itu, hasil pekerjaan mahasiswa yang ditempel semestinya dikomentari mahasiswa untuk kemudian dikembalikan dosen kepada mahasiswa sebagai evaluasi. See II, proses pembelajaran PTK pada siklus II sudah berjalan baik sesuai scenario yang telah dibuat. Mahasiswa lebih konsentrasi dalam proses pembelajaran, hal ini disebabkan upaya dosen model dalam membimbing dan mengarahkan mahasiswa sudah sangat baik. Namun demikian, ada beberapa hal yang perlu diperbaiki, di antaranya dosen model perlu memberi kesempatan yang sama kepada semua mahasiswa agar kegiatan presentasi tidak hanya terfokus kepada mahasiswa yang pandai. Mahasiswa juga perlu diberi kesempatan untuk lebih mengeksplorasi materi. Terakhir, mahasiswa perlu diberi kesempatan untuk saling menukar lembar kerja mahasiswa, sehingga mahasiswa dapat saling berbagi pengalaman dan pendapat. Pada see III, pembelajaran sudah berjalan cukup baik. Dosen berinteraksi dengan mahasiswa.

Ada beberapa hal yang perlu diperbaiki dalam proses pembelajaran selanjutnya, yaitu mahasiswa masih memerlukan penjelasan tentang siklus Pembelajaran IPS, lembar kerja mahasiswa (LKM) hendaknya disediakan lebih awal dan format LKM dibuat sesederhana mungkin sehingga memudahkan mahasiswa untuk mengisi dan memahami unsur apa saja yang terkait dengan metode. Sementara itu, dalam see IV diperoleh masukan bahwa sebagian mahasiswa belum memahami substansi permasalahan penelitian dan masih kesulitan dalam menetukan indikator. Untuk itu, dosen model perlu memberikan penjelasan yang lebih rinci. Pada proses pembelajaran siklus IV ini, mahasiswa lebih aktif dan berani memaparkan hasil kerja yang mereka buat. Mahasiswa juga lebih memperhatikan penjelasan dosen dan paparan teman. Dengan demikian dapat dikatakan bahwa proses belajar mengajar pada siklus ini berjalan dengan baik. 


\section{Hasil yang Dicapai}

Pembelajaran mata kuliah Pembelajaran IPS pada siklus I berjalan sesuai dengan rencana materinya adalah IPS berbasis masalah. Dosen menggunakan metode diskusi untuk mengarahkan mahasiswa. Dosen juga menyediakan media berupa kertas tempel sehingga mahasiswa mampu memberikan gambaran tentang pengertian pembelajaran IPS yang ditulis oleh mahasiswa. Selama proses pembelajaran berlangsung, mahasiswa tampak konsentrasi mengerjakan tugas dan lembar kerja mahasiswa (LKM) yang diberikan dosen. Dalam proses mengerjakan tugas atau mengisi lembar kerja mahasiswa (LKM), mahasiswaberdiskusi dengan teman sekelompoknya agar mahasiswa dapat saling bertukar pikiran dan saling berbagi pengetahuan atau ide.

Mahasiswa yang masih merasa kebingungan dalam mengerjakan tugas merasa terbantu oleh proses diskusi dengan teman dalam kelompok. Dengan demikian, mahasiswa benar-benar telah belajar tentang topik perkuliahan. Selain itu, dosen memberikan kesempatan kepada mahasiswa untuk bertanya tentang hal-hal yang belum dipahaminya. Dosen juga berkeliling memantau proses belajar mahasiswa dan memberikan pengarahan terhadap mahasiswa. Pengalaman atau hasil yang dicapai dalam proses pembelajaran ini adalah mahasiswa merasa terdorong untuk bekerja atau mengerjakan tugas dengan baik. Mahasiswa dapat bekerja sama dengan temantemannya sehingga ada proses saling memberi dan menerima. Dengan metode diskusi, mahasiswa dilatih untuk mempertajam daya nalar/ kemampuan berpikir.

Siklus II, materi pembelajarannya adalah mempelajari metode maupun teknik pembelajaran. Dosen masih menggunakan metode diskusi dalam proses pembelajaran. Dalam pembelajaran IPS kali ini, mahasiswa memanfaatkan kesempatan berdiskusi untuk menyelesaikan lembar kerja yang dibagikan oleh dosen. Mahasiswa diminta untuk membuat atau menyusun bahan yang akan dipergunakan dalam penyusunan kajian pustaka. Ada beberapa mahasiswa yang masih merasa kebingungan. Namun demikian, pengarahan dosen dan masukan dari sesama mahasiswa dapat 
membantu mempermudah belajar mahasiswa. Hasil yang dicapai dalam proses ini adalah mahasiswa dapat memetakan topik yang dibahas dan mengaitkannya dengan teori. Mahasiswa lebih berkonsentrasi dalam proses pembelajaran dan mahasiswa juga menjadi sangat terbantu dengan adanya diskusi . Dengan demikian, tugas dosen hanyalah sebagai fasilitator. Materi diberikan pada siklus III adalah konsep dan kurikulum 13.Proses ini dilakukan di kelas dengan bimbingan dosen. Dosen memberikan lembar kerja mahasiswa. Tampaknya mahasiswa masih merasa kebingungan karena mahasiswa masih belum memahami bagaimana cara mengerjakan lembar kerja mahasiswa.

Melihat kondisi seperti ini, dosen segera membimbing dan mengarahkan mahasiswa serta meminta mahasiswa untuk berdiskusi dengan teman sekelompoknya. Mahasiswa yang pada awalnya merasa kebingungan akhirnya dilaksanakan dengan baik. Hasil yang dicapai dalam kegiatan ini adalah mahasiswa semakin terbiasa dengan kelas terbuka. Mahasiswa juga semakin aktif dalam berdiskusi dan mahasiswa yang tadinya bersikap individualis pada akhirnya menjadi sedikit terbuka dan mau berbagi dengan sesama teman. Dengan demikian dapat dikatakan bahwa proses diskusi memberikan dampak yang positif bagi mahasiswa.

Siklus IV merupakan siklus terakhir dalam kegiatan lesson study. Pada siklus ini, mahasiswa diminta untuk memahami materi pendidikan karakter dalam pembelajar IPS. Namun demikian, contoh dan media yang diberikan dosen cukup membantu mahasiswa dalam mema-hami materi. Selain itu, pemberian kesempatan kepada mahasiswa untuk bertanya dan menjawab pertanyaan yang telah disediakan pada lembar kerja mahasiswa dapat mendorong mahasiswa untuk belajar dengan baik. Hasil yang diperoleh dalam kegiatan siklus IV ini adalah mahasiswa terdorong untuk semakin aktif. Mahasiswa dapat menggali pengetahuan secara lebih luas dan mahasiswa terlatih untuk berani menjawab pertanyaan. Dosen memberikan solusi atas kesulitan mahasiswa karena ada komunikasi yang baik antara dosen dan mahasiswa. 
Kontribusi Program dalam Rangka Meningkatkan Kualitas Pembelajaran Lesson study pada dasarnya merupakan suatu kegiatan yang mampu mendorong terbentuknya sebuah komunitas belajar yang secara konsisten melakukan continous improvement baik pada level individu, kelompok, maupun pada sistem yang lebih.

Program lesson study dirasakan sangat bermanfaat untuk peningkatan kualitas pembelajaran. Berdasarkan angket yang disebarkan kepada mahasiswa terkait dengan kontribusi lesson study dalam rangka meningkatkan kualitas pembelajaran, mahasiswa menilai bahwa pembelajaran dengan model lesson study lebih menarik dan membuat mahasiswa semakin antusias. Hal ini disebabkan ada beberapa dosen yang masuk kelas sebagai observer/ pengamat, sehingga proses pembelajaran dirasakan semakin baik kualitasnya dan menyenangkan. Sebagai contoh, ketika mahasiswa sedang berdiskusi, mahasiswa dapat memperbaiki kekurangan/ kesalahan pada tugas yang dikerjakan karena ada masukan dari teman sekelompok maupun teman dari kelompok lain. Mahasiswa dapat memperoleh pengalaman saling berbagi ide dan pengetahuan dengan teman sekelas. Dengan demikian mahasiswa dapat meningkatkan kualitas belajarnya.

Ada beberapa karakter yang muncul pada diri mahasiswa ketika mereka mengikuti proses pembelajaran dengan model lesson study, yaitu mahasiswa menjadi berani dan percaya diri. Hal ini dapat terlihat ketika mereka diberi kesempatan untuk menuangkan hasil pemikirannya dalam media pembelajaran maupun ketika mereka mempresentasikan ide kreatifnya atau hasil diskusi kelompoknya. Mahasiswa yang tadinya cenderung tertutup dan sulit berkomunikasi akhirnya dapat mengubah dirinya menjadi pribadi yang terbuka dan mau berbagi dengan teman sekelompoknya. Hal ini terlihat ketika mereka berdiskusi, ada proses saling memberi dan menerima, ada proses saling mengisi untuk menyempurnakan tugas yang diberikan oleh dosen. Dengan demikian, mahasiswa dapat merasakan hakikat belajar yang sesungguhnya. Hal ini tentu tidak dapat dilepaskan dari kontribusi 
dosen model yang memberikan pengarahan, rangsangan, dan penghargaan terhadap hasil kerja keras mahasiswa.

Selain itu, proses pembelajaran membuat mahasiswa nyaman, karena dosen lebih memperhatikan mahasiswa satu per satu. Dosen juga memberikan rangsangan kepada mahasiswa terkait dengan materi yang sudah diberikan maupun materi yang akan disampaikan pada pertemuan saat itu. Proses pembelajaran dinilai sangat interaktif dan sangat kondusif. Menurut mahasiswa, dalam kegiatan lesson study materi yang diberikan dosen dinilai lebih rinci dan selalu ada proses perbaikan dari dosen baik itu dari segi persiapan, media, maupun prengelolaan kelas. Hal ini disebabkan adanya rekaman pembelajaran yang dilakukan oleh tim lesson study maupun lembar observasi yang diisi oleh observer.

\section{Kendala yang Dihadapi dan Upaya yang Dilakukan}

Ada beberapa kendala yang dihadapi tim dalam kegiatan lesson study yang sudah dilakukan. Kendala tersebut dapat terselesaikan dengan baik ketika tim LS melakukan evaluasi. Adapun kendala yang dimaksud dapat dilihat pada uraian berikut.

a) Pemilihan media pembelajaran.

Tim LS mengalami kendala dalam menentukan media yang sesuai untuk kelas besar (dengan kemampuan mahasiswa yang beragam). Menghadapi kendala seperti ini, tim memutuskan untuk membuat lembar kerja mahasiswa yang akan memudahkan mahasiswa dalam materi pembelajaran IPS. Selain lembar kerja mahasiswa, tim juga menyiapkan contoh proposal PTK untuk memberikan gambaran kepada mahasiswa.

b) Pemantauan softskill mahasiswa. Kegiatan lesson study yang terbatas oleh waktu menyebabkan tim agak kesulitan dalam memantau softskill mahasiswa. Jumlah mahasiswa yang relatif banyak dan tim LS yang tidak mengetahui nama-nama mahasiswa yang terlibat LS juga semakin menyulitkan tim. Untuk mengatasi hal ini, tim meminta mahasiswa untuk membuat papan nama yang harus dipakai ketika mengikuti proses pembelajaran di kelas. Untuk memantau dan memastikan bahwa mahasiswa telah 
terasah softskillnya, tim membuat video rekaman pembelajaran dan membuat angket terkait dengan softskill mahasiswa.

\section{Tindak Lanjut Program yang Direncanakan}

Program kegiatan lesson study merupakan program yang dinilai sangat bermanfaat untuk perbaikan proses pembelajaran. Untuk itu perlu adanya tindak lanjut program yang dapat terus dilakukan agar proses pembelajaran di perguruan tinggi semakin berkualitas. Tim LS Prodi Pendidikan Guru Madrasah Ibtidayah telah merencanakan beberapa hal untuk menindaklanjuti program $L S$, yaitu:

a) Mengupayakan kegiatan lesson study tidak hanya terbatas pada kegiatan pengabdian, baik yang dibiayai dari dana blockgrant maupun dana universitas. Kegiatan yang baik ini sebaiknya dilaksanakan setiap kali proses pembelajaran dengan cara membentuk team teaching pada setiap mata kuliah.

b) Tim LS merencanakan untuk berbagi pengalaman dengan teman sejawat tentang pentingnya kegiatan lesson study dalam bentuk diskusi kecil.

c) Tim LS akan mengembangkan model pembelajaran agar proses pembelajaran berjalan lebih efektif dan efisien walaupun dengan jumlah mahasiswa yang sangat banyak.

\section{Penutup}

Hasil yang dicapai dari pelaksanaan lesson study ini adalah sebagai berikut.

1) Dengan model pembelajaran cooperatif learning mahasiswa terdorong untuk menyampaikan materi dengan baik, ada proses saling memberi dan menerima antarmahasiswa, dan kemandirian mahasiswa juga terlihat ketika mahasiswa diminta untuk mengisi lembar kerja mahasiswa. Dalam proses pembelajaran ini, ada peningkatan soft skill mahasiswa dalam penyusunan proposal PTK.

2) Interaksi antara dosen dan mahasiswa terjalin dengan baik. Selain itu, dosen juga berusaha untuk Lebih kreatif dan inovatif 
dalam mempersiapkan materi, mengelola kelas, dan membuat media pembelajaran. Hal ini berdampak pada peningkatan antusiasme mahasiswa dalam mengikuti proses pembelajaran.

3) Pemilihan metode diskusi dalam materi pembelajaran IPS membawa dampak pada penguatan karakter mahasiswa. Mahasiswa menjadi lebih mandiri, mau saling berbagi dengan teman sekelompok maupun sekelasnya, mahasiswa juga lebih berani/percaya diri dalam mengungkapkan pendapatnya, dan mahasiswa berusaha untuk bekerja keras menyelesaikan materi agar dapat dipresentasikan di hadapan teman-temannya.

4) Proses pembelajaran IPS semakin baik, karena ada perencanaan, pelaksanaan, dan refleksi yang dilakukan secara berkesinambungan. Dengan demikian ada pembelajaran secara bersama-sama oleh tim pengajar, saling memberi koreksi antar kolega, dan proses evaluasi pembelajaran yang melibatkan dosen dan mahasiswa.

\section{Daftar Pustaka}

Hendayana, Sumar, dkk. Lesson Study, Suatu Strategi Untuk Peningkatan Keprofesionalan Pendidik. Bandung: FPMIPA UPI dan JICA, 2007.

Iskandarwassid, dan Dadang Sunendar. Strategi Pembelajaran Bahasa. Bandung: Remaja Rosdakarya, 2008.

Kemendiknas. Pedoman Penulisan Makalah Lesson Study untuk Seminar Exchange of Experience. Direktorat Pembelajaran dan Kemahasiswaan Direktorat Jenderal Pendidikan Tinggi Kementerian Pendidikan Nasional. Jakarta, 2012.

Kesuma, Dharma, dkk. Pendidikan Karakter, Kajian Teori dan Praktik di Sekolah. Bandung: PT. Remaja Rosdakarya, 2011.

Khairani. Panduan Penyusunan Proposal Penelitian Dengan Mudah. Padang: UNP Press, 2009.

Slameto. Belajar dan Faktor-Faktor yang Mempengaruhinya. Jakarta: Rineka Cipta, 2003. 
Sugiarti, dkk."Peningkatan Kemandirian dan Daya Kritis Mahasiswa Semester V Prodi Bahasa, Sastra Indonesia dan Daerah FKIP UMM pada Mata kuliah Penelitian Bahasa dan Sastra Indonesia”, makalah Seminar Lesson Study FKIP UM, 2012.

Sugiyono. Metode Penelitian Kuantitatif Kualitatif dan R\&D. Bandung: Alfabeta, 2010.

Uno, Hamzah B dan Nurdin Mohamad. Belajar dengan Pendekatan PAILKEM: Pembelajaran Aktif, Inovatif, Lingkungan, Kreatif, Efektif, Menarik. Jakarta: PT. Bumi Aksara, 2011.

Wahyuni, Sri. Dkk. Peningkatan Kemandirian Belajar Fisika Biologi Pada Mahasiswa Semester I Angkatan Tahun 2011 Program Studi Pendidikan Biologi FKIP UMM. Artikel Ilmiah untuk Jurnal, 2011. 